\title{
Tumbuhan Nyamplung (Chalohyllum inophyllum Linn) dan Bioaktifitasnya
}

\section{Nyamplung (Chalohyllum inophyllum Linn) and Its Bioactivities}

\section{Emilda}

\author{
Program Studi Pendidikan Biologi, FMIPA, Universitas Indraprasta PGRI, Indonesia \\ Korespnden: emilda1430@ gmail.com
}

\begin{abstract}
Abstrak
Nyamplung (Calophyllum inophyllum L) adalah tumbuhan yang tersebar luas di Indonesia, terutama ditemukan di daerah pantai berpasir. Tumbuhan dengan pohon tinggi sedang ini sudah lama digunakan masyarakat sebagai obat. Keragaman metabolit sekunder yang dikandungnya memiliki potensi untuk dikembangkan sebagai bahan baku obat untuk industri obat. Artikel ini ditulis berdasarkan literatur ilmiah untuk menjelaskan hubungan pemanfaatan Nyamplung (Chalohyllum inophyllum L.) dengan bioaktifitasnya sehingga pemanfaatannya sebagai obat dapat dikembangkan. Berdasarkan sejumlah penelitian tentang metabolit sekunder ditemukan senyawa terutama kelompok xanthone, kumarin, triterpenoid dan flavonoid. Senyawa ini memiliki bioaktivitas termasuk antikanker, antivirus, anti-HIV, antibakteri, antijamur, dan antiinflamasi.
\end{abstract}

Kata kunci : Calophyllum inophyllum, Tumbuhan Obat, Bioaktifitas

\section{Abstract}

Nyamplung (Calophyllum inophyllum L) is a plant that is widespread in Indonesia, especially found in sandy coastal areas. The plants with medium tall trees have long been used by the community as medicine. The diversity of secondary metabolites has the potential to be developed as medicinal raw materials for the drug industry. This article is written based on a scientific literature to explain the relationship between the use of Nyamplung (Chalohyllum inophyllum L.) with its bioactivity to develop its utilization as a drug. Based on a few of researches on secondary metabolites found mainly groups of xanthones, coumarins, triterpenoids and flavonoids. These compounds have bioactivity including anticancer, antiviral, anti-HIV, antibacterial, antifungal, and anti-inflammatory.

Keywords : Calophyllum inophyllum, Medicinal Plant, Bioactivities

\section{PENDAHULUAN}

Pemanfaatan tumbuhan atau hewan untuk pengobatan telah menjadi tradisi yang turun temurun ditengah masyarakat. Pengetahuan lokal ini turut mendorong eksplorasi obat dari bahan hayati. Saat ini, meskipun dunia pengobatan modern telah berkembang tren penggunaan obat dari bahan alam terus ada bahkan cenderung meningkat. Lembaga kesehatan dunia WHO menyebutkan bahwa $80 \%$ penduduk dunia cenderung menggunakan produk herbal. WHO juga merekomendasikan penggunaan herbal untuk pemeliharaan kesehatan, pencegahan dan pengobatan penyakit kronis, degeneratif dan kanker (Bappenas, 2016). 
Data Survei Sosial Ekonomi Nasional atau Susenas 2017 menunjukkan terjadi peningkatan minat dalam penggunaan obat tradisional di Indonesia. Sebanyak 32 persen orang Indonesia masih menerapkan pengobatan tradisional untuk mengobati penyakit. Kemudian, lebih kurang 22,3 persen orang Indonesia memilih pengobatan dengan tumbuhtumbuhan atau herbal, seperti tanaman, buah-buahan, umbi, dan akar tanaman.

Disamping itu, pentingnya penelitian dan pengkajian terhadap bahan hayati yang berpotensi obat disebabkan kebutuhan bahan baku obat bagi industri obat juga terus meningkat, sementara 90-95\% bahan baku obat ini masih diimpor. Padahal kekayaan sumberdaya hayati Indonesia sangat berlimpah dan beranekaragam. Data LIPI (2014) menyebutkan spesies flora yang terdata terdiri dari 1,500 jenis alga, tumbuhan sporofit terdiri atas 80,000 jenis jamur, 595 jenis lumut kerak, 2,197 jenis paku serta spermatophyta sebanyak 30.000-40.000 spesies. Diantaranya 9600 spesies tumbuhan diketahui memiliki khasiat obat. Hanya saja sebagian besar data tentang tumbuhan obat ini baru seputar etnobotaninya. Sementara data-data lebih lanjut yang bisa digunakan sebagai dasar pemanfaatannya sebagai obat belumlah cukup.

Tumbuhan Nyamplung (Chalohyllum inophyllum L) memiliki sejumlah manfaat bagi kehidupan manusia. Masyarakat memanfaatkan Nyamplung sebagai tumbuhan penghasil bahan bakar dan obat-obatan tradisional. Permanasari (2010) mengutip Heyne (1987) menyebutkan bahwa air yang digunakan untuk merendam daun Nyamplung dapat digunakan untuk mencuci mata yang meradang. Minyak pada bijinya dapat digunakan untuk mengobati sakit kulit, menumbuhkan rambut dan beberapa penyakit lainnya. Masyarakat Dayak Ngaju di Kalimantan Tengah terbiasa menggunakan getah batang penaga jangkar (Chalohyllum inophyllum) yang berwarna kuning ketika mereka terserang koreng atau gatal (Setyomati dkk, 2005). Sedang masyarakat Dayak Suru' menggunakan Calophyllum sp sebagai bahan pewarna (Joni dkk, 2015). Pada masyarakat China, tumbuhan ini biasa digunakan untuk pengobatan sakit mata, rematik, peradangan, dan luka (Kainuma et al., 2016).

Berdasarkan hal diatas, penulisan artikel ini bertujuan untuk memberikan informasi tentang hubungan pemanfaatan Nyamplung (Chalohyllum inophyllum L.) dengan bioaktifitasnya sehingga pemanfaatannya sebagai obat dapat dikembangkan. 


\section{METODOLOGI}

Penulisan artikel ini berdasarkan kajian kepustakaan dengan pendekatan deskriptif berdasarkan pustaka sekunder dari artikel-artikel penelitian dan teks ilmiah lainnya. Penelusuran pustaka digali melalui situs google (www.google.co.id) dan google scholar (www.scholar.google.co.id). Kata kunci yang digunakan diantaranya Nyamplung, Chalohyllum inophyllum L, bioaktifitas, phytochemistry, anti HIV dsb.

\section{HASIL SAN PEMBAHASAN}

\section{Botani Nyamplung (Chalohyllum inophyllum L.)}

Chalohyllum inophyllum L termasuk anggota dari famili Clusiaceae. Famili ini terdiri atas 20 genus dengan 1200 spesies. Nama Chalohyllum berasal dari bahasa Yunani yaitu dari kata 'kalos'- indah dan 'phullon'- daun. Artinya daun yang cantik (Warrier, 2010). Di Indonesia Chalohyllum inophyllum L dikenal dengan nama camplung, Nyamplung, bintanguru, benaga, bintangur laut, menaga, naga (Noor dkk, 1999).

Nyamplung (Chalohyllum inophyllum Linn.) adalah spesies pohon sedang hingga besar. Tumbuhan ini memiliki sebaran yang luas di dunia mulai dari Afrika, India, Asia Tenggara, Australia Utara, dan lain-lain. Di Indonesia dijumpai hampir di seluruh wilayah, terutama pada daerah pesisir pantai (Leksono dkk, 2014). Habitatnya berada pada ketinggian 0 hingga $200 \mathrm{~m}$ di atas permukaan laut dengan curah hujan antara 1.000-3.000 mm/tahun. Menurut Noor dkk (1999) Nyamplung tumbuh pada habitat bukan rawa dan pantai berpasir. Pohonnya berwarna gelap, berdaun rimbun, tingginya antara 10-30 m. Umumnya tumbuh agak bengkok, condong atau bahkan sejajar dengan tanah. Memiliki getah lekat berwarna putih atau kuning.

Daun tunggal bersilang-berhadapan bulat memanjang atau bulat telur. Memiliki banyak urat dengan posisi lateral paralel dan halus. Bagian atas daun berwarna hijau tua dan mengkilap, bagian bawahnya hijau agak kekuningan. Tipe bunganya majemuk dan menghasilkan bau yang harum. Umumnya biseksual, namun terkadang uniseksual fungsional. Bentuk tandan di ketiak daun yang teratas, diameter $2-3 \mathrm{~cm}$, tujuh sampai tiga belas, daun kelopak empat tidak beraturan, daun mahkota empat, lonjong, putih. Buah muda berwarna 
hijau dan yang sudah tua berwarna kekuning-kuningan, apabila dibiarkan lama buah berwarna seperti kayu, buah termasuk kategori buah batu, bulat seperti peluru dengan mancung kecil di depannya, panjangnya antara 25-50 mm. Biasanya buah muncul 2 kali setahun. Biji berbentuk bulat tebal dan keras, berukuran relatif besar berdiameter $2-4 \mathrm{~cm}$, daging biji tipis dan biji yang telah kering dapat tahan disimpan selama 1 bulan, inti biji mengandung minyak berwarna kuning kecoklatan (Leksono dkk, 2014; Warrier, 2010; Friday dan Okano, 2006).

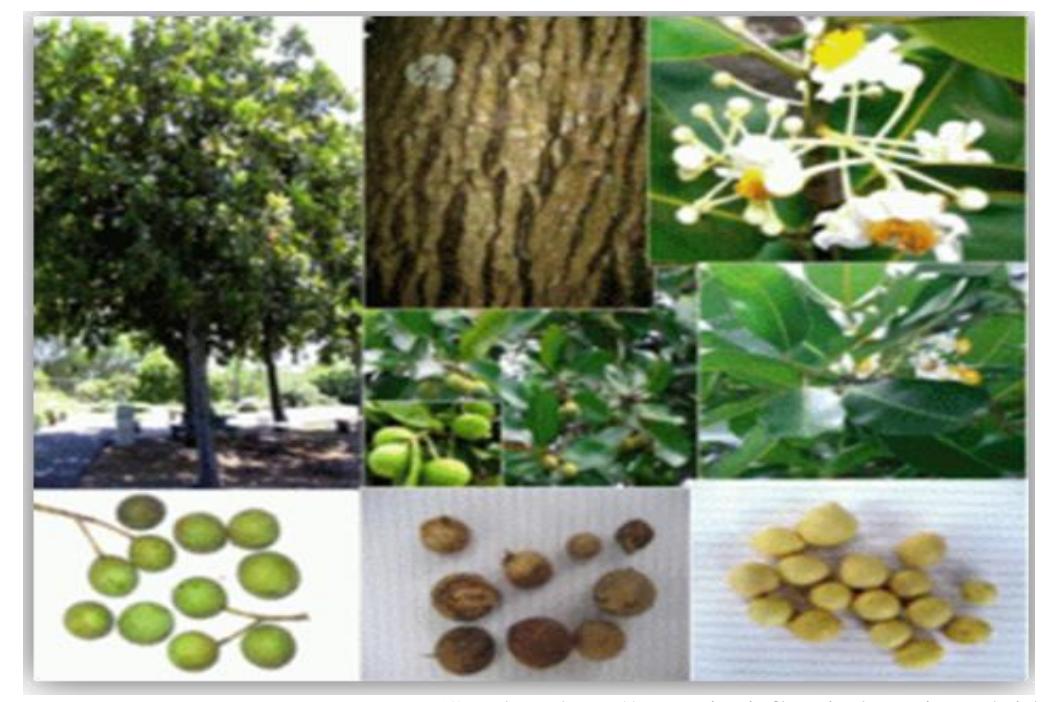

(Sumber: http://www.jenisfloraindonesia.web.id)

Gambar 1. Karakteristik Pohon dan Buah Nyamplung

Nyamplung dikategorikan sebagai spesies pohon serba guna dan memiliki potensi tinggi sebagai bahan baku biodiesel dengan 74\% kandungan zat produktif (Departemen Kehutanan, 2008). Sejumlah penelitian menyebutkan rendemen minyak Nyamplung 40-70\% tergolong tinggi dibandingkan jenis tanaman lain. Penelitian Suyono dkk (2017) memperoleh rendemen minyak dari Nyamplung hingga $82,87 \%$. Selain itu, bagian-bagian tumbuhan Nyamplung lainnya juga digunakan untuk berbagai keperluan. Kayunya dapat dimanfaatkan untuk konstruksi ringan, lantai, cetakan, bengkel tukang kayu, palet kayu, papan selam, roda gandar dan as roda, alat musik hingga membuat sumpit. Senyawa racun yang ditemukan pada daun bisa digunakan sebagai racun ikan dan insektisida.

Selain itu, biji Nyamplung diketahui memiliki kandungan minyak tinggi. Penelitian Bustomi et al., (2008) dalam Mukhlisi dan Sidiyasa (2011) melaporkan bahwa biji Nyamplung dapat diolah menjadi biodiesel dengan tingkat rendemen yang cukup tinggi (40- 
73\%). Fadhlullah et al., (2015) melaporkan bahwa pohon Nyamplung dari Cipatujuh Tasikmalaya berpotensi menghasilkan minyak sebanyak 5,13/L/pohon/tahun.

\section{Fitokimia Tumbuhan Nyamplung}

Hampir seluruh bagian tumbuhan Nyamplung (Calophyllum inophyllum L.) dapat dimanfaatkan sebagai bahan obat. Baik daun, akar, kulit batang, buah, biji, minyak dari biji serta getahnya. Berbagai penelitian telah mengungkap keragaman kandungan senyawametabolit sekunder pada tumbuhan ini. Praveena et al., (2013) menyatakan senyawa yang diekstraksi dari Calophyllum inophyllum terdiri dari kelompok steroid/triterpenoidal glycoside dan kelompok kumarin (kumarin atau calophyllic acid). Kainuma et al., (2016) menyebutkan pada C.inophyllum banyak ditemukan senyawa xanthon, kumarin dan triterpenoid. Xanthon ditemukan pada ranting, cabang, batang, kulit batang, akar, kulit akar serta kayunya. Sedang kumarin dan triterpenoid teridentifikasi pada daunnya. Kumarin merupakan senyawa paling dominan ditemukan pada biji dan minyak biji.

Berdasarkan penelitian Susanto dkk (2017), dalam ekstrak kasar daun C. inophyllum ditemukan $11.51 \%$ alkaloid, $2.48 \%$ triterpenoid, $2.37 \%$ flavonoid, $7.68 \%$ tanin, $2.16 \%$ saponin, $2.53 \%$ polifenol. Dari hasil analisis GC-MS ditemukan sembilan senyawa yaitu Phytol, Methyl Oleate, Linoleic acid, 5-Aminomethyl-dibenzosuberane, 2-Phenazinamine, Diphenylmethane, Carbazole dan Adenanthin (Saravanan et al., 2015). Minyak biji Nyamplung selain digunakan sebagai salah satu sumber biodiesel juga mengandung senyawa kimia yang bermanfaat. Ekstrak kasar minyak biji Nyamplung mengandung komponen steroid, flavonoid, saponin, dan triterpenoid (Hasibuan dkk, 2013). Kartika et al., (2018) menyebutkan bahwa biji Nyamplung yang diekstrak dengan n-heksana mengandung asamasam berupa palmitat, palmitoleat, stearat, oleat, linoleat, linolenat, arakidat, eikosenoat dan behenat. Yang paling banyak adalah asam oleat, linoleat dan asam stearat. Sedang getahnya mengandung inophyllum A-E, calophyllic acid, kelompok kumarin, fenol, polifenol, triterpenoid dan flavonoid.

Sichaem et al., (2018) menemukan 18 senyawa kimia pada kulit akar C.inophyllum termasuk kumarin, xanton, triterpenoid dan flavonoid. Diantaranya terdapat 9 senyawa yang baru ditemukan yaitu caloinophyllin B; 3,3',4',5,7-pentametoksiflavon; 1,8-dimetoksixanton; 
1,6-dihidroksi-7-metoksixanton;3-hidroksi-4-metoksixanton;3-hidroksi-2-metoksixanton;2,3dimetoksixanton; 1,6-dihidroksixanton dan 1,3,5-trihidroksixanton.

\section{Bioaktifitas Tumbuhan Nyamplung}

Kandungan senyawa kimia Nyamplung yang beragam, menghasilkan bioaktifitas juga sangat banyak. Penelitian-penelitian yang banyak mengeksplor bioaktifitas umumnya baru skala in vitro. Diantaranya sebagai antioksidan, antikanker (Raju dan Victoria, 2015), antivirus, anti HIV (Ragasa et al., 2015 dan Kainuma et al., 2016), anti inflamasi, antibakteri, antidiuretik, antidiabetes dll. Beberapa diantaranya akan dibahas dalam tulisan ini.

\section{Antifungi dan Antibakteri}

Fungi atau jamur mikroskopis termasuk kelompok mikroba yang dapat menyebabkan penyakit dan menimbulkan kerusakan pada makanan. Nyamplung yang diekstraksi dengan campuran etanol, kloroform dan air menghasilkan senyawa friedelin, calophyllol, inophynon yang menunjukkan aktifitas antifungi. Hal ini ditunjukkan dengan kemampuan menekan pertumbuhan fungi dari jenis Tricophyton simi dan Tricophyton mentagrophytes yang dapat menyebabkan dermatofitosis pada manusia dan hewan. Ekstrak kloroform juga mampu melawan fungi yang bersifat patogen pada manusia seperti Psuedallescheria boydii, Aspergillus niger, Candida albicans. Begitupula senyawa triterpen yang mampu melawan jamur jenis Aspergillus niger, Pseudallescheria boydii,dan Trichophyton schoenleinii (Ali et al., 1999 dalam Ragasa et al., 2015)

Manfaat lain dari senyawa metabolit sekunder yang dihasilkan tumbuhan ini adalah sebagai anti bakteri. Menurut Ragasa et al., (2015) senyawa triterpen 1 yang diekstrak dari C.inophyllum menunjukkan kemampuan melawan bakteri Staphylococcus aureus, Corynebacterium diptheriae, Salmonella typhi, Klebsiella pneumonia, dan Proteus mirabilis.

Penelitian Adewuyi et al., (2014) juga menunjukkan aktifitas antibakteri dari ekstrak asetonid biji C.inophyllum. Minyak biji mampu menghambat pertumbuhan Escherichia coli, Salmonella typhi, dan Pseudomonas aeruginosa serta mampu mematikan bakteri Bacillus subtilis dan Staphylococcus aureus. Penelitian Hasibuan dkk (2013) bahwa minyak Nyamplung tidak memiliki efek antibakteri pada E.coli tapi memiliki efek antibakteri terhadap Staphylococcus aureus.

Mishra et al. (2010) melaporkan bahwa ekstrak metanol dari kulit batang Calophyllum inophyllum memiliki kemampuan antibakteri yang signifikan dalam melawan Pseudomonas 
aeurginosa, Staphylococcus aureus and Staphylococcus epidermidis pada konsentrasi 25 $\mu \mathrm{g} / \mathrm{ml}$. Sedang aktifitas antibakteri pada Bacillus licheniformis, Bacillus subtilis, Escherichia coli dan Klebsiella pneumoniae terjadi pada konsentrasi $50 \mu \mathrm{g} / \mathrm{ml}$. Pada kajian sebelumnya disebutkan bahwa aktifitas antibakteri ini dihasilkan dari senyawa tanin dan fenol yang terkandung didalamnya, disamping karena adanya senyawa alkaloid (Susanto dkk, 2017)

Senyawa kumarin dan derivatnya seperti calophyllolid dan inophyllolid yang terdapat dalam minyak Nyamplung juga berpotensi untuk menghambat pertumbuhan fungi mikroskopis. Meadow dan Dweck (2002) menyebutkan kumarin memiliki efek antibiotik, antibakteri dan anti jamur. Mekanisme kerja kumarin dalam menghambat pertumbuhan jamur belum diketahui secara pasti. Diduga senyawa ini dapat menghambat DNA gyrase subunit B yang berperan melepaskan untai ganda DNA sehingga menyebabkan DNA mengalami superkoiling (Lewis et al., 1996 dalam Mladenovic, 2010) serta menghambat pengambilan glukosa oleh jamur yang tumbuh pada $M$. smithii serta menghambat enzim-enzim pada proses metabolisme mikroorganisme (Cansunar et al., 1990).

\section{Anti Inflamasi}

Terjadinya inflamasi atau peradangan adalah indikator perlawanan sistem imunitas tubuh terhadap suatu penyakit. Fungsinya adalah untuk menghancurkan, mengurangi, serta melokalisasi agen pencedera maupun jaringan yang cedera. Biasanya obat antiinflamasi yang beredar adalah AINS (Antiinflamasi Non Steroid) dan AIS (Antiinflamasi Steroid). Senyawa anti inflamasi yang potensial adalah yang dapat memberikan efek kemopreventif pada karsinogenesis.

Berbagai penelitian yang mengkaji manfaat senyawa metabolit sekunder dari Nyamplung menemukan bahwa salah satu fungsinya sebagai antiinflamasi. Zakaria et al., (2012) melaporkan dari hasil uji in vitro menunjukkan ekstrak kasar C. inophyllum dengan konsentrasi $50 \mu \mathrm{g} / \mathrm{ml}$ mampu menghambat aktifitas siklooksigenase sebesar $77 \%$ dan aktifitas lipooksigenase $88 \%$. Kedua enzim ini berperan dalam pengubahan asam arakidonat menjadi hidroperoksid ketika inflamasi terjadi. Senyawa yang diisolasi oleh Zakaria et al., (2012) adalah Inophyllum A, inophyllum C, inophyllum E, calophylloide, calophynic acid, 11,12anhydroinophyllum A, 1,7-dihydroxy-6-methoxyxanthone, potocatechuic acid, gallic acid, nnonacosane, $\beta$-sitosterol and sitosterol-3-O- $\beta$-D-glucopyranoside. 
Kim et al., (2004) menjelaskan aktifitas senyawa flavonoid melalui penghambatan enzim penghasil eicosanoid seperti fosfolipase A2, siklooksigenase dan lipooksigenase, sehingga mengurangi konsentrasi prostanoid dan leukotrien. Pada tingkat ekspresi gen menurut Tsai et al., (2012) ekstrak C.inophyllum menghambat produksi oksida nitrit dan menurunkan regulasi gen-gen inducible nitric oxide synthase (iNOS), cyclooxygenase (COX)-2 dan nuclear factor-kappaB (NF-kB).

\section{Antikanker}

Penelitian Jaikumar et al., (2016) menunjukkan terdapat aktivitas antikanker dari ekstrak etanol daun Nyamplung dengan nilai IC50 120 $\mu \mathrm{g} / \mathrm{mL}$. Ekstrak daun ini memperlihatkan kemampuan melawan pertumbuhan sel MCF-7. Senyawa metabolit sekunder yang terdapat dalam ekstrak menyebabkan penghambatan terhadap proliferasi sel kanker dan mengakibatkan apoptosis alami. Hsieh et al., (2017) melaporkan bahwa pigmen kuning dan hijau yang diekstrak dari minyak biji Nyamplung bersifat sitotoksik pada sel kanker kolon (DLD-1). Begitupula pada sel A549 dan H1975 penyebab kanker paru-paru dengan nilai IC50 0,1206\% dan 0,0676\%.

Uji MTT dan CyQuant yang dilakukan Shanmugapriya et al., (2016) pada ekstrak buah C. Inophyllum menunjukkan kemampuan penghambatan terhadap sel kanker MCF-7 dengan nilai IC50 yang diperoleh adalah $19.63 \mu \mathrm{g} / \mathrm{mL}$ untuk uji MTT dan $27.54 \mu \mathrm{g} / \mathrm{mL}$ untuk CyQuant. Ekstrak buah ini menunjukkan efek antitumor yang signifikan pada sel MCR-7 dengan nilai IC50 23,59 $\mu \mathrm{g} / \mathrm{ml}$. Hal ini disebabkan kemampuan menginduksi penangkapan siklus sel pada fase G0/G1 dan G2/M serta apoptosis. Calophyllum inophyllum menekan ekspresi BCL-2, protein anti-apoptostik, sementara menginduksi proapoptosis BAX, p53 dan sitokrom C. Ekstrak mempengaruhi jalur apoptosis mitokondria dengan meningkatkan spesies oksigen reaktif intraseluler (ROS), mengganggu potensi mitokondria normal dan mengaktifkan kaspase-3.

\section{Antivirus dan Anti HIV}

Senyawa metabolit sekunder dalam C.inophyllum juga memiliki kemampuan antivirus. Seperti triterpenoid memiliki sejumlah bioaktifitas sebagai bakterisidal, fungisidal, antivirus, antikanker, spermisidal, kardiovaskular, analgesik dan anti-alergik (Patočka, 2003 dalam Kainuma et al., 2016). Termasuk informasi dari berbagai penelitian yang menyebutkan ditemukannya potensi anti HIV pada C.inophyllum 
Laure et al., (2008) dalam Win (2018) melaporkan senyawa dipyranocoumarinscalophyllolid, inophyllum $B, C, G$ dan $P$ yang diekstraksi dari biji dan daun Nyamplung diketahui memberikan efek terhadap penghambatan terhadap enzim reverse transcriptase non nukleocide (NNRT). Inophyllum $\mathrm{B}$ and $\mathrm{P}$ menghambat enzim reverse transcriptase dengan nilai IC50 38 dan $130 \mathrm{nM}$. Inophyllum juga menyebabkan gangguan pertumbuhan HIV-1. Enzim NNRT sendiri adalah enzim yang dibutukan virus HIV unhtuk menjadi DNA secara utuh sehingga bisa bereplikasi dalam sel tubuh. Begitupula ekstrak campuran etanol dan air dari bagian kulit batang memberikan pengaruh signifikan sebagai anti HIV-IN karena melakukan penghambatan terhadap enzim HIV-1 integrase (Narayan et al., 2011 dalam Ragasa et al., 2015).

Selain untuk bahan obat, senyawa metabolit sekunder yang bersifat sitotoksik pada Nyamplung juga bisa digunakan untuk pestisida. Warrier (2010) menyebutkan asap pembakaran dari buah matang Nyamplung bersifat repellent pada nyamuk dan getah dari batang juga bersifat racun pembunuh untuk tikus dan pembius bagi ikan. Salah satunya penelitian Santi (2014) menunjukkan adanya potensi sebagai pestisida alami dari ekstrak biji Nyamplung, sebab mengandung senyawa anti feedant dan menurunkan nafsu makan pada larva kepik (Epilachna sparsa).

\section{KESIMPULAN}

Berdasarkan tulisan diatas dapat disimpulkan bahwa tumbuhan Nyamplung (Calophyllum inophyllum L) mengandung senyawa metabolit sekunder yang sangat banyak, utamanya kelompok senyawa santon, kumarin, triterpenoid dan flavonoid. Berdasar sejumlah penelitian, bioaktifitas yang ditunjukkan oleh Nyamplung juga beragam. Diantaranya adalah sebagai antikanker, antivirus, anti HIV, antibakteri, antifungi, dan anti inflamasi.

\section{REFERENSI}

Adewuyi, A; Fasusi, O.H dan Oderinde, R.A. 2014. Antibacterial Activities of Acetonides Prepared From The Seed Oils of Calophyllum inophyllum and Pterocarpus osun. Journal of Acute Medicine. Vol. 4(2): 75-80 
Kementerian Perencanaan Pembangunan Nasional/Bappenas. 2016. Indonesian Biodiversity Strategy and Action Plan 2015-2020. Kementerian Perencanaan Pembangunan Nasional/Bappenas. Jakarta.

Cansunar, E; Anthony, J.R; Graham, W dan Colin, S.S. 1990. Effect of coumarin on glucose uptake by anaerobic rumen fungi in the presence and absence of Methanobrevibacter smithii. FEMS Microbiology Letters. Vol. 70(2): 157-160

Departemen Kehutanan. 2008. Nyamplung (Calophyllum inophyllum L.) Sumber Energi Biofuel yang Potensial. Pusat Informasi Kehutanan. Jakarta.

Dweck, A.C dan Meadow, T. 2002. Tamanu (Calophyllum inophyllum) - the African, Asian, Polynesian and Pacific Panacea. International Journal of Cosmetic Science. Vol. 24(6): 341-348.

Friday, J.B dan Okano, D. 2006. Calophyllum inophyllum (kamani), ver.2.1. In: Elevitch, C.R. (ed.). Species Profiles for Pasivic Island Agroforestry. Permanent Agriculture Resources (PAR), Hōlualoa, Hawai'i. ( www.traditionaltree.org). Diakses 7 Juli 2019.

Hasibuan, S; Sahirman dan Yudawati, M.A. 2013. Karakteristik Fisikokimia Dan Antibakteri Hasil Purifikasi Minyak Biji Nyamplung (Calophyllum inophyllum L.). Agritech. Vol. 33(30):311-319

Hsieh, C; Yun-Wei, L; Ching-Hsein, C; Wenjun. K; Fuching M; Hanming, Y dan Chishih, C. 2017. Yellow and green pigments from Calophyllum inophyllum L. seed oil induce cell death in colon and lung cancer cells. Oncology Letters. Vol. 15(4): 5915-5923.

Jaikumar, K. Md; Sheik, N.M; Anand, D dan Saravanan, P. 2016. Anticancer Activity of Calophyllum Inophyllum L., Ethanolic Leaf Extract In MCF Human Breast Cell Lines. Int J Pharm Sci Res. Vol. 7(8): 3330-3335.

Kainuma, M; Baba, S; Chan, H.T; Inoue, T; Tangah, J; Wei, E. 2016. Medicinal Plants of Sandy Shores: A Short Review on Calophyllum inophyllum and Thespesia populnea. International Journal of Pharmacognosy and Phytochemical Research. Vol. 8(12):2056-2062

Kartika, I.A; Cerny, M; Vandenbossche, V; Rigal, L; Sablayrolles, C; Vialle C; Suparno, O; Ariono, D dan Evon, Ph. 2018. Direct Calophyllum oil extraction and resin separation with a binary solvent of $n$-hexane and methanol mixture. Open Archive TOULOUSE Archive Ouverte. Diakses 14 Juli 2019

Kim, H.P; Son, K.H; Chang, H.W dan Kang, S.S. 2004. Anti-inflammatory Plant Flavonoids and Cellular Action Mechanisms. J Pharmacol Sci. Vol. 96 (3): 229 - 245.

Leksono, B; Windyarini, E dan Hasnah, T.M. 2014. Budidaya Nyamplung (Calophyllum Inophyllum L.) Untuk Bioenergi dan Prospek Pemanfaatan Lainnya. Bogor. IPB Press.

Lembaga Ilmu Pengetahuan Indonesia. 2014. Kekinian Keanekaragaman Hayati Indonesia. LIPI Press. Jakarta.

Mishra, U.S; Murthy, P.N; Choudhury; P.K; Panigrahi, G; Mohapatra, S dan Pradhan, D. 2010. Antibacterial and Analgesic Effects of the Stem Barks of Calophyllum inophyllum. Int.J. ChemTech Res. Vol. 2(2): 973-979. 
Mladenovic, M; Vuković, N; Sukdolak, S dan Solujić, S. 2010. Design of Novel 4-Hydroxychromene-2-one Derivatives as Antimicrobial Agents. Molecules. Vol. 15(6):42944308 .

Mukhlisi dan Sidiyasa, K. 2011. Aspek Ekologi Nyamplung (Calophyllum inophyllum L.) di Hutan Pantai Tanah Merah, Taman Hutan Raya Bukit Soeharto (Some Ecological Aspects of Nyamplung (Calophyllum inophyllum L.) at Tanah Merah Coastal Forest, Taman Hutan Raya Bukit Soeharto). Jurnal Penelitian Hutan dan Konservasi Alam. Vol. 8(3):385-397

Noor, Y.R; Khazali, M dan Suryadiputra, I.N.N. 1999. Panduan Mengenal Mangrove di Indonesia. PHKA/WI-IP. Bogor.

Permanasari, D. 2010. Isolasi dan Identifikasi Senyawa Caloxanthone B dari Kulit Batang Nyamplung (Calophyllum inophyllum Linn). (Skripsi). UNS. Diakses 14 Juli 2019

Praveena, Ch; Swaroopa, R.S dan Veeresham, C . 2013. Phytochemical Investigation of Calophyllum inophyllum Linn. Natural Products Chemistry \& Research. Vol. 1(4):1-4

Ragasa, C.Y; Ebajo, V; Reyes, M.D, Mandia, E.H; Brkljača, R dan Urban, S. 2015. Triterpenes from Calophyllum inophyllum Linn. International Journal of Pharmacognosy and Phytochemical Research. Vol. 7(4): 718-722.

Raju, D.C dan Victoria, T.D. 2015. Phytochemical Screening and Bioactivity Studies of Immature and Mature Leaves of Calophyllum inophyllum.L. Journal of Chemical and Pharmaceutical Sciences. Vol. 8(1):46-51

Santi, S.R. 2014. Senyawa Antimakan Pada Minyak Biji Nyamplung (Calophyllum inophyllum L). Jurnal Kimia. Vol. 8(2): 226-230

Saravanan, P; Jaikumar, K; Sheik, N.M.M dan Anand, D. 2015. Phytochemical Analysis of Bioactive Compounds from Calophyllum inophyllum L., Leaf Extract Using GC-MS Analysis. International Journal of Pharmacognosy and Phytochemical Research. Vol. 7(5): 956-959

Shanmugapriya; Yeng, C; Jagat, R.K; Sreenivasan, S. 2016. Effects of Calophyllum inophyllum fruit extract on the proliferation and morphological characteristics of human breast cancer cells MCF-7. Asian Pacific Journal of Tropical Disease. Vol. 6(4):291297

Sichaem, J; Santi, T dan Pongpun, S. 2018. Chemical Constituents from the Root Bark of Calophyllum inophyllum. Natural Product Communications. Vol. 13(6):727 - 729

Susanto, D.F; Hakun, W.A; Arief, W; Setiyo, G. 2017. Identification of phytochemical compounds in Calophyllum inophyllum leaves. Asian Pacific Journal of Tropical Biomedicine. Vol. 7(9):773-781

Suyono; Hartanti, N.U; Wibowo, A dan Narto. 2017. Biodisel dari Mangrove Jenis Nyamplung (Callophylum inophyllum) sebagai Alternatif Pengganti Bahan Bakar Minyak Fosil. Biosfera. Vol. 34(3):123 -130 
Tsai, Sc; Yu-Hsin, L; Jo-Hua, C; Fon-Chang, L; Wen-Hsin, L; Shu-Jen, C; Wei-Yu, L; Chieh-Hsi, W dan Jing-Ru, W. 2012. Anti-inflammatory effects of Calophyllum inophyllum L. in RAW264.7 cells. Oncology Reports. Vol. 28(3):1096-1102

Warrier, K.C.S. 2010. Manual of Econornically Important F orestry Species in South India. Tamil Nadu. Institute of Forest Genetics and Tree Breeding. Coimbatore. India

Win, M.O. 2018. Pharmacological Properties of Calophyllum inophyllum -Updated Review. International Journal of Photochemistry and Photobiology. Vol. 2(1): 28-32.

Zakaria, M; Vijayasekaran; Zul, I; Nur, A.M. 2014. Anti-Inflammatory Activity of Calophyllum inophyllum Fruits Extracts. Procedia Chemistry. Vol. 13.218 - 220. 